\title{
Slavery at the Court of the 'Humanist Prince' Reexamining Johan Maurits van Nassau-Siegen and his Role in Slavery, Slave Trade and Slave-smuggling in Dutch Brazil
}

\author{
Carolina Monteiro \\ PhD Candidate, Faculty of Archaeology, Leiden University, Leiden, \\ the Netherlands \\ c.monteiro@arch.leidenuniv.nl \\ Erik Odegard \\ Head of the research project "Revisiting Dutch Brazil and Johan Maurits", \\ the Royal Picture Gallery Mauritshuis, The Hague, The Netherlands; \\ Lecturer in Economic History, Institute for History, Leiden University, \\ Leiden, the Netherlands \\ e.odegard@mauritshuis.nl
}

\begin{abstract}
From 1630 until its fall in 1654, the Dutch West India Company maintained a colony in northeastern Brazil where it tried to profit from the cultivation of sugar using enslaved African labor. Count Johan Maurits van Nassau-Siegen served as this colony's governor-general from ${ }_{16} 6{ }_{6}$ until 1644 , this being the most heavily studied period of the colony's existence. But the role of Johan Maurits in the transatlantic slave trade and enslavement in Brazil is poorly covered by research, with some historians recently arguing that there is 'no proof' of any personal involvement. This article presents a clear argument for the personal involvement of Johan Maurits in the slave trade and shows his involvement in slave-smuggling. Understanding the social relations between the count, his court and the Luso-Brazilian elite is in fact simply impossible without bringing in the trade and smuggling of enslaved Africans.
\end{abstract}




\section{Keywords}

Dutch Brazil - Dutch West India Company (wIC) - Johan Maurits van Nassau-Siegen slave trade - smuggling - Dutch Atlantic

\section{Introduction}

From 1630 until 1654 the Dutch West India Company (WIC) maintained a colony in northeastern Brazil, which at its greatest extent encompassed the coastal areas of the present-day states of Alagoas, Pernambuco, Paraíba, Rio Grande do Norte, Ceará and Maranhão. The Dutch colony in Brazil has enjoyed a recent resurgence of interest, with Wim Klooster arguing that the attempt to capture Brazil and its sugar industry was of profound importance not just to the Republic and the wIC, but also to the Atlantic World at large. ${ }^{1}$ The colony in Brazil is commonly associated with the figure of Johan Maurits van NassauSiegen (1604-1679), who served as the wIC's governor-general from 1636 until 1644. In the Dutch system of colonial governance, sending nobility abroad was relatively rare and the fact that the governor of Brazil was of the House of Nassau explains many of the unique features of the colony within the frame of Dutch Early Modern colonialism more broadly. Once in Brazil, Johan Maurits proceeded to construct a court befitting a protestant German nobleman with princely aspirations. 'Construction' entailed both the physical construction of palaces and gardens as well as the social construction of a retinue of courtiers whose presence at the court and whose work lent prestige to the court and the count. ${ }^{2}$ The historiography of the Dutch colony in Brazil in general, and of the period in which Johan Maurits governed specifically presents two faces to the audience, scholarly and otherwise. On the one hand, there are many (especially art-historical) studies of the court, the artists and their work and

1 Wim Klooster, The Dutch Moment: War, Trade, and Settlement in the Seventeenth-Century Atlantic World (Ithaca: Cornell University Press, 2016).

2 For the gardens see: Maria Angélica da Silva and Melissa Mota Alcides, 'Collecting and Framing the Wilderness: The Garden of Johan Maurits (1604-79) in North-East Brazil', Garden History 30:2 (2002): 153-176; for the architecture: J.J. Terwen, 'The Buildings of Johan Maurits van Nassau', in: Ernst van den Boogaart, Hans R. Hoetink and Peter James Palmer Whitehead (eds.), Johan Maurits van Nassau-Siegen 1604-1679. A Humanist Prince in Europe and Brazil: Essays on the Occasion of the Tercentenary of his Death (The Hague: Mauritshuis, 1979), 54-141. Regarding Johan Maurits's courtly protocols as political strategy, see: Arno Wehling, 'A Organização Política do Brasil Holandês e o Papel das Liturgias de Poder no Governo de Nassau,' in: Vera Lúcia Bottrel Tostes, Sarah Fassa Benchetrit and Aline Montenegro Magalhães (eds.), A Presença Holandesa no Brasil: Memória e Imaginário, (Rio de Janeiro: Museu Histórico Nacional, 2004), 11-30. 
the scientific output which extoll the virtues of the count. On the other hand, studies on Dutch Brazil more broadly stress the fact that the colony was lost with great loss of life and invested money, and that failure in Brazil doomed the wic. ${ }^{3}$

Brazilian historiography on the period also tends to focus on the loss of the colony and the process of restoration that ensued. The revolt leading up to Portuguese recovery of the colony is often seen as the first effort that 'Brazilians' (as distinct from metropolitan Portuguese) undertook in gaining control over their territory. ${ }^{4}$ The 'Nassovian' administration is used as a point of comparison for both previous and subsequent Portuguese governments. ${ }^{5}$ More often than not, Johan Maurits is praised as a Brazilian himself, whose governing decisions are usually disassociated from his position as an employee of the WIC. ${ }^{6}$

Constructed throughout the centuries, the positive perception of the Dutch period in Brazil is still alive in Brazilian society up to the present date. This perception is usually based on the idea that rule by Johan Maurits's, being a nobleman, brought progress and civilization. ${ }^{7}$ Especially in Pernambuco, Dutch Brazil is, thus, still part of the social imagination as is indicated by

3 For examples of the scientific and artistic work: suppress Peter James Palmer Whitehead and Martin Boeseman, A Portrait of Dutch $17^{\text {th }}$ Century Brazil: Animals, Plants and People by the Artists of Johan Maurits of Nassau (Amsterdam: North Holland Publishing Company, 1989); Ernst van den Boogaart and Frits Duparc eds., Zo Wijd de Wereld Strekt: Tentoonstelling naar Aanleiding van de 3ooste Sterfdag van Johan Maurits van Nassau-Siegen op 20 December 1979 (The Hague: Mauritshuis, 1979). For the consequences of the loss of Brazil for the WIC and the Dutch Atlantic: Wim Klooster and Gert Oostindie, Realm Between Empires: The Second Dutch Atlantic, 1680-1815 (Ithaca: Cornell University Press, 2018), 22-23.

4 Examples include: Evaldo Cabral de Mello, Olinda Restaurada: Guerra e Açúcar no Nordeste, 1630-1654 (São Paulo: Editora Forense-Universitária 1975); Evaldo Cabral de Mello, O Negócio do Brasil: Portugal, os Países Baixos e o Nordeste, 1641-1669 (Rio de Janeiro: Topbooks, 1998); Wolfgang Lenk, Guerra e Pacto Colonial: A Bahia Contra o Brasil Holandês, 1624 - 1654 (São Paulo: Alameda Casa Editorial, 2013). The interpretation has been criticized as simplistic and romantic by Lilia M. Schwarcz and Heloisa M. Starling, Brazil: A Biography (New York: Farrar, Straus and Giroux, 2018), 52-53.

5 The term 'Nassauvian' was probably first used by Gilberto Freyre in the article cited in footnote 6 . The term was picked up and updated by Evaldo Cabral de Mello, for example in $O$ Bagaço da Cana (Rio de Janeiro: Penguin, 2012), 36, where the title of a chapter is 'Euforias Nassovianas', and also used in his earlier Rubro Veio: O Imaginário da Restauração Pernambucana (Rio de Janeiro: Editora Nova Fronteira, 1986), 329, where one chapter is entitled 'Nostalgia Nassoviana'.

6 Gilberto Freyre, 'Johan Maurits van Nassau-Siegen from a Brazilian Viewpoint', in: Boogaart, Hoetink and Whitehead (eds.), A Humanist Prince in Europe and Brazil: Johan Maurits van Nassau-Siegen 1604-1679, 237-246.

7 Evaldo Cabral de Mello studies the 'nativist' imaginary of Pernambuco as of the Portuguese restoration in Rubro Veio, mentioned in footnote 5. Throughout the book the author points out different moments in Brazilian historiography and politics in which the Dutch occupation 
monuments and commemorations referring with some enthusiasm to the WIC's presence in northeast of Brazil. ${ }^{8}$

For the Dutch Republic and the WIC, Brazil came with substantial opportunity costs and the focus on the South Atlantic system of Brazil and Angola came at the expense of neglect of the Caribbean and North America. ${ }^{9}$ In older histories, all that went well in Brazil is described as due to the presence of Johan Maurits, while all ills were despite his strenuous efforts. The count is thus presented as a one-dimensional figure, a 'humanist prince in the tropics,' in the words of Charles Boxer. ${ }^{10}$ It is fair to argue that to a considerable extent, the scholarly focus on Johan Maurits has generally cannibalized attention from Dutch Brazil in general. While he continues to be at the heart of recent research, the period following his departure is poorly covered in the historiography, although the colony would last for another ten years. ${ }^{11}$ But even the figure of Johan Maurits himself and his tenure in Brazil have raised new questions. This article will explore one previously understudied element of Johan Maurits's tenure in Brazil: his personal involvement in enslavement and the transatlantic slave trade.

period has been either condemned or praised, according to contemporary personal and social interests.

In 2004, Germany donated a sculpture with the bust of Johan Maurits to the 'people of Pernambuco.' As a copy of the original located at Johan Maurits's tomb in Siegen, the monument stands today at the Republican Square in Recife. Johan Maurits's last name 'Nassau' is also given to bridges, streets and even to a private university with campuses in different cities throughout Brazil.

Jaap Jacobs, The Colony of New Netherland: A Dutch Settlement in Seventeenth-Century America (Leiden: Brill, 2005), 178-187.

10 Charles Boxer, The Dutch in Brazil, 1624-1654 (Oxford: Clarendon Press, 1957), 112.

11 New interpretations include: A new interpretation of Johan Maurits's career by taking into account insights from gender studies is: Susie Protschky, 'Between Corporate and Familial Responsibility: Johan Maurits van Nassau-Siegen and Masculine Governance in Europe and the Dutch Colonial World', in: Susan Broomhall and Jacqueline van Gent (eds.), Governing Masculinities: Regulating Selves and Others in the Early Modern Period (Farnham: Ashgate, 2011), 108-20. Arthur Weststeijn, 'Machiavelli in Dutch Colonial Ideology: Caspar Barlaeus, Johan Maurits of Nassau and the Imperial Prince', Storia del Pensiero Politico 2 (2017): 1-20. A good example of the traditional imbalance in the study of Dutch Brazil is provided by: Pieter Marinus Netscher, Les Hollandais au Brésil: Notice Historiques sur les Pays-Bas et le Brésil sur le XVIIe Siècle (The Hague: Belinfante Frères, 1853), 83-140 on the Johan Maurits period, while the decade afterwards is covered in pages 141-165; an exception is Cabral de Mello, O Negócio do Brasil, which focusses on the negotiations on Brazil leading up to the treaty of The Hague of $1662 / 3$. 
Johan Maurits was appointed to lead a colony whose sole economic raison d'être was the production of sugar using unfree labor and where enslaved Africans were not only a form of economic, but also social capital. We may reasonably hypothesize that the governor of the colony, in seeking to underline his social status over and above the class of sugar-mill owners, would seek to acquire a retinue of slaves. Professionally, the success - measured in terms of profitability - of the colony depended on the transshipment of sufficient numbers of enslaved Africans to maintain and expand sugar production. It was argued at the time that two thousand new arrivals a year were necessary to maintain sugar production. ${ }^{12}$ By 1637 there were still 106 mills in operation in Dutchheld territories. ${ }^{13}$ Yet the personal involvement of Johan Maurits in both the slave trade and enslavement of people in Brazil remains a point of contention, as is evident from a recent debate sparked by the removal of a (replica-)bust of Johan Maurits from the foyer of the Mauritshuis museum. ${ }^{14}$ Two eminent historians argued that income from slavery and slave trade formed only part of Johan Maurits's income during his tenure in Brazil. ${ }^{15}$ This was a revision of an earlier position of one of the authors, who had argued that 'If Johan Maurits left Brazil richer than he arrived there, those capital gains consisted of his salary paid by his employer, the West India Company, and a percentage of the spoils of war.'16

This raises the question this article will explore. Did Johan Maurits personally profit from the trade and sale of enslaved Africans, and if so, how did this revenue stream relate to his 'official' income of salary and spoils? The involvement of Johan Maurits in the trade in enslaved Africans and their forced labor

12 José Antônio Gonsalves de Mello, Tempo dos Flamengos: Influência da Ocupação Holandesa na Vida e na Cultura do Norte do Brasil (5th edition, Rio de Janeiro: Topbooks, 2007 [1947]), 188n17.

13 Stuart B. Schwartz, 'A Commonwealth within Itself: The Early Brazilian Sugar Industry, 1550-1670', in: Stuart B. Schwartz (ed.), Tropical Babylons: Sugar and the Making of the Atlantic World, 1450-1680 (Chapel Hill: University of North Carolina Press, 2004), 166.

14 Lukas van den Berge, 'Dealing with Ambiguity: Johan Maurits, Black Pete and the Crisis of Dutch Identity', Netherlands Journal of Legal Philosophy 47:1 (2018): 3-12.

15 Pieter Emmer and Henk den Heijer, 'Niet Alles Had in de Gouden Eeuw met Slavenhandel te Maken, dus Laten we ook niet Doen alsof', De Volkskrant, 30-4-2019.

16 Pieter Emmer, 'Het slavernijverleden van het Mauritshuis', Historiek.nl (31-7-2014), https:// historiek.net/het-slavernijverleden-van-het-mauritshuis/44119/ 'Als hij rijker uit Brazilië is vertrokken dan hij er naar toe gegaan is, dan bestond die vermogensaanwas uit gespaard salaris betaald door zijn werkgever, de West-Indische Compagnie (wIC) en uit een percentage van de krijgsbuit.' 
in the colony is, despite recent protestations to the contrary, actually poorly researched..$^{17}$ This article will argue that there is in fact ample evidence that Johan Maurits van Nassau-Siegen was not only personally involved in keeping Africans enslaved in Brazil, he did in fact profit personally from the trade and transshipment of humans from Africa to Brazil. Our goal is not retroactive condemnation, which would be rather pointless, but to show that it is naive to think we can separate the 'superstructure' of the court, its artistry, architecture and - strategically inspired - ideas on religious toleration, from the basic economic structure of the colony, which was centered on slavery. Brazil was a slave society rather than a society with slaves, and the institution of slavery formed the corner-stone of the economic, political, and social structure of the colony. ${ }^{18}$ Indeed, the court of Johan Maurits in Brazil, including the artistic output it produced is simply unimaginable without the enslaved labor which made the court run and which in part financed its operations. If we attempt to deny this reality we do our understanding of the period and the colony a disservice.

We will argue the importance of Johan Maurits's position as slave owner and the importance of slave labor for the running of his court. We will examine his role as a purchaser of enslaved Africans and finally his role as a slave-smuggler in contravention of the rules of the WIC. To do this we will draw on archival material, some of which is entirely new, and we will use the account of Frei Manuel Calado (1584-1654) of the interactions of the wider court of Johan Maurits with the Luso-Brazilian elite. This account has often been dismissed as the collected gossip of a self-involved court. ${ }^{19}$ But by combining the account of Calado with Dutch archival sources we can argue in favor of the reliability of

17 Jos Joosten, 'Wat Literair Erfgoed ons over Vandaag Vertelt: Hoe 'Vaderlands' en 'Heldhaftig'was Johan Maurits van Nassau Eigenlijk?', Ons Erfdeel 62:1 (2019): 78-83, 82, argues that the topic has long been researched, referring to: Luiz Felipe de Alencastro, 'Johann Moritz und der Sklavenhandel' in: Gerhard Brunn and Cornelius Neutsch (eds.), Sein Feld war die Welt, Johann Moritz von Nassau-Siegen (1604-1679): von Siegen über die Niederlanden und Brasilien nach Brandenburg (Münster: Waxman, 2008), 123-144. This article is, however, a small extract of Alencastro's extensive research about slavery in Brazil, including the Dutch period; Luiz Felipe de Alencastro, O Trato dos Viventes: Formação do Brasil no Atlântico Sul, Séculos XVI e XVII, (9th edition, São Paulo: Editora Schwarcz, 2016), recently translated to English as: The Trade in the Living: The Formation of Brazil in the South Atlantic, Sixteenth to Seventeenth Centuries, (New York: State University of New York Press, 2018).

18 Ira Berlin, Many Thousands Gone: The First Two Centuries of Slavery in North America (Cambridge Mass.: Belknap Press of Harvard University Press, 1998), 8; Alencastro, O Trato dos Viventes, 353 .

19 José Antônio Gonsalves de Mello, Frei Manuel Calado do Salvador: Religioso da Ordem de São Paulo, Pregador Apostólico por Sua Santidade, Cronista da Restauração (Recife: Universidade de Recife, 1954), 8, refers to Francisco Adolfo de Varnhagen and Hermann Wätjen 
his account insofar as the detailed cases of slave-smuggling are concerned. The realization that Calado's account is in fact backed up by other archival material means we should perhaps study this source more attentively. More broadly, the case of slave-smuggling detailed by Calado which is at the heart of this article showcases the increasing tensions between the colonial government of Brazil headed by Johan Maurits and the wIC directors in the Netherlands. The realization that their governor was involved in attempts to circumvent or undermine the company's claimed exclusivity in the African trades may have formed an important reason to push for his dismissal in $1642-1644$. It also provides a crucial background for the strong refusal of the directors to even entertain the notion of bringing Angola and Brazil under one government, something which Johan Maurits argued in favor of. ${ }^{20}$

\section{$3 \quad$ Perceptions of Johan Maurits}

In the spring and summer of 1636 , the WIC was anxiously seeking a new form of government for its Brazilian colony. The military and civilian command of the colony were in constant conflict with one another and a new, centralized, command-structure had been advised by many in the colony. On July 28,1636 , Albert Coenraetsz Burgh, wIC director on behalf of the chamber Amsterdam proposed that Johan Maurits van Nassau-Siegen be asked to take up the newlycreated position of 'Admiral-, Captain-, and Governor-General of the Brazilian Coast.'21 The choice was in many ways unusual, Johan Maurits did not have any commercial or administrative experience and had commanded an infantry regiment in the States' army when he was nominated. It is possible that the nomination by Burgh was a form of recompense to stadtholder Frederik Hendrik for intervening in Amsterdam against radical Calvinist preachers earlier that decade. ${ }^{22}$

The image of Johan Maurits as a Governor of Dutch Brazil that is perhaps most entrenched in the public and scholarly mind is that painted by Charles

as being critical of the book, although Gonsalves de Mello himself was positive. Charles Boxer also frequently cited Calado.

20 Klaas Ratelband, Nederlanders in West-Afrika, 16oo-1650. Angola, Kongo, São Tomé (Zutphen: Walburg Pers, 2000), 171-172.

21 National Archives of the Netherlands, The Hague (hereafter NL-HaNA), 1.05.01.01, Old West India Company (hereafter OwIC), inv.no. 2, 253.

22 Erik Odegard, Colonial Careers:Johan Maurits van Nassau-Siegen, Rijckloff Volckertsz. van Goens, and Career-Making in the Seventeenth-Century Dutch Empire (PhD dissertation, Leiden, 2018), 66-76. 
Boxer in his classic The Dutch in Brazil, which presented Johan Maurits as a laudable 'humanist prince in the tropics.' Even before Boxer, Hermann Wätjen and Pieter Netscher had propagated the positive image of Johan Maurits, depending in no small part on the magnum opus of Caspar Barlaeus: Rerum per Octennium in Brasilia, et Alibi Nuper Gestarum sub Praefectura J. Mauritii Nassoviae, published in $1647 .{ }^{23}$ Barlaeus had been requested to write the book by Johan Maurits and could draw upon the count's personal archives to do so. This makes it a troublesome source, however, as the book is exceptionally laudatory of the count. ${ }^{24}$ Ironically, the same is true of the other great seventeenth century work on the wIC published by Johannes de Laet, the Iaerlyck Verhael. In presenting his book to the company directors, De Laet mentioned that his reason for writing this history of the company from 1621 to 1644 was 'solely to preserve the memory of all things which our Company so laudably accomplished and to stimulate the Government to further maintain and subsidize this Company.'25

But other contemporary accounts were by no means as positive as the image of the wise and beneficent ruler that Johan Maurits himself tried to propagate. Pierre Moreau, in his Klare en Waarachtige Beschryving on the fall of Brazil complained that Johan Maurits had in fact captured the future leaders of the revolt against the Dutch but had been bribed to release them. In fact, Moreau asserted that Johan Maurits had been most blatantly accepting bribes and enriched himself more than anyone else in the service of the company before leaving Brazil. ${ }^{26}$ Clearly, Moreau, writing two years before the final fall of the last strongholds in Brazil in 1654 had very distinct views on the topic of the performance of Johan Maurits. Nor can this view have come as a great shock to his audience, as it is mentioned in passing, without giving much

23 Netscher, Les Hollandais au Brésil, 83-140, describes the 'Nassovian' period. The table of contents on page $\mathrm{x}$ styles the period as the 'prospérité et richesse de la colonie', contrasted to the period of 'décadence rapide' that followed it.

24 Caspar Barlaeus, Rerum per Octennium in Brasilia et Alibi Gestarum, sub Praefectura ill. Comitis I. Mauritii Nassaviae \&c Comitis, Historia (Amsterdam: Johannes Blaeu 1647). Barlaeus's account has also been translated into Dutch, German, English and Portuguese. A recent edition in English is: Caspar van Baerle and Blanche T. van Berkel-Ebeling Koning, History of Brazil under the Governorship of Count Johan Maurits of Nassau, 1636-1644 (Gainesville: University Press of Florida, 2011).

25 Leiden University Library, PAP 2, Letters of De Laet to the Directors of the wic, letter 2. '... alleen is geweest de memorie te bewaeren van tgene soo lofflycken bij onse Compagnie is verricht ende dat de Regeeringh daer door opgewect mochte werden om de welgemelte Compagnie voorder te handhaven ende subsidieren....

26 Pierre Moreau, Klare en Waarachtige Beschryving van de Leste Beroerten en Afval der Portugezen in Brasil; daar in d'Oorsprong dezer Zwarigheden en Oorlogen Klarelijk Vertoont Worden (Amsterdam: Jan Hendriksz. en Jan Rieuwertsz, 1652). 
heed to potential different views. A very different kind of evaluation of Johan Maurits's performance in Brazil was given by Willem Frederik van NassauDietz (1613-1664), Stadholder of Friesland (1640-1664), Groningen and Drenthe (1650-1664) in his remarkably candid diary. Willem Frederik was a rival of Johan Maurits for the position of general of the Dutch cavalry, so his account may be assumed to be hostile to Johan Maurits. On the other hand, Willem Frederik was of the same social status as Johan Maurits and could judge his performance from a perspective which is difficult for a contemporary historian to appraise: the idea of a nobleman's honor. Willem Frederik criticized Johan Maurits for failing to communicate with the company's directors and depending solely on the favor of the stadtholder and the States-General. ${ }^{27}$ Hendrick van de Capellen, the fifth candidate contacted to replace Johan Maurits, refused to go to Brazil 'in the service of the merchants', as this would be detrimental to his honor and they, having so mistreated Johan Maurits, were not deserving of his services. ${ }^{28}$

Manuel Calado, resident in Pernambuco during Johan Maurits's tenure proposed yet another view. Despite being one of the main figures in fomenting the insurrection, the Portuguese friar had conflicting opinions regarding Johan Maurits and the WIC. While he considered the Company to be composed of 'mere merchants, tyrannical creatures who treated the people of Dutch Brazil worse than animals,' he also saw Johan Maurits as a benevolent prince, whom he would call his Excellency, 'for his noble blood inclined him to do good.'29 Francisco de Brito Freyre, whom historian Gonsalves de Mello considers to be one of the first admirers of Johan Maurits, did not hesitate, however, in belittling the count on the front page of his 1675 publication Nova Lusitânia: História da Guerra Brasilica. The fall of Dutch Brazil is represented on the front page of the volume by four eroded classical columns, a wandering armadillo and a Portuguese galleon whose cask is inscribed with the words: 'Qua Non Patet Orbis.' A clear derisive allusion to Johan Maurits's motto 'Qua Patet Orbis' (as far as the world reaches), present in Caspar Barlaeus Rerum per Octennium. ${ }^{30}$

27 Willem Frederik van Nassau and G.N. van der Plaat (ed.), Gloria Parendi: Dagboeken van Willem Frederik, Stadhouder van Friesland, Groningen en Drenthe, 1643-1649, 1651-1654. Dagboek 1643 (The Hague: Nederlandsch Historisch Genootschap, 1995), 21.

28 Alexander Bick, Governing the Free Sea: The Dutch West India Company and Commercial Politics, 1618-1645 (PhD dissertation, Princeton, 2012), 153 .

29 Manuel Calado, $O$ Valeroso Lucideno e Triunfo da Liberdade $\left(4^{\text {th }}\right.$ edition, Recife: Fundarpe, 1985), 94 .

30 Francisco de Brito Freyre, Nova Lusitânia, História da Guerra Brasílica (Recife: Governo de Pernambuco, 1977[1675]). Franscisco de Brito Freyre was a Portuguese admiral against the Dutch occupation in Brazil in the 165os. Brito Freyre became Governor-General of Pernambuco after it returned to Portuguese hands from 1661 to 1664 . 
Recent historiography has also turned towards a more critical reflection of Johan Maurits's tenure in Brazil. Close examination of the sources, especially the archives of the WIC itself, leads historians to conclude that Johan Maurits was not the brilliant success as a governor or military man that he tried to portray himself as. ${ }^{31}$ This shift in expert opinion is not uncontested. In a roundtable on Wim Klooster's The Dutch Moment, Joyce Goodfriend criticized his reluctance to lauding Johan-Maurits for his well-known accomplishments of transplanting elements of Dutch science, architecture and art to Brazil, preferring instead to cast him as an imperfect ruler. But Johan Maurits's attempt to create an urban culture in Recife that resembled that of cities in the homeland was a deliberate effort to bridge the two faces of seventeenth-century Dutch culture. ${ }^{32}$ Goodfriend's arguments are interesting as they aptly summarize the views of a much broader historiographical tradition. ${ }^{33}$ The interpretation of Johan Maurits as a Dutchman, and the creation of a 'Dutch urban culture' in the Mauritsstad-Recife complex does require some elaboration, however. For we argue that to understand Johan Maurits and his actions in Brazil, but also afterwards, we need to see him not as a Dutchman, but as a German. Specifically, Johan Maurits was a member of a German-bound junior branch of the Nassau family without any territories or holdings inside the Dutch Republic. ${ }^{34}$ This meant that he lacked an immediate and natural voice in Dutch provincial politics and that a governmental career, natural to much of Dutch nobility, was not immediately open to him. Military service provided a suitably honorable employment for a nobleman of course, but when reviewing Johan Maurits's later life, his main goals seem to have been his elevation to princely status within the Holy Roman Empire. This German aspect is also visible in Brazil. Rather than interpreting the Mauritsstad-Recife complex as replication of a Dutch urban culture, it is possible to interpret it as a replication of a protestant

31 Klooster, The Dutch Moment, 67; Michiel van Groesen, Amsterdam's Atlantic: Print Culture and the Making of Dutch Brazil (Philadelphia: University of Pennsylvania Press, 2017), $125^{-126 .}$

32 Trevor Burnard, Joyce Goodfriend, Cynthia Van Zandt, Willem Frijhoff and Wim Klooster, 'The Empire That Never Was: The Nearly-Dutch Atlantic Empire in the Seventeenth Century,'Journal of Early American History 7:1 (2017): 33-80, 49.

33 The urban planning of Recife has garnered some scholarly attention. See for example: José Luis Motta de Menezes, 'A Cidade de Maurício,' in Tostes, Benchetrit and Magalhães (eds.) A Presença Holandesa no Brasil, 185-196.

34 In 1607 , the territory of Siegen yielded a yearly revenue of $f 13,000$. This was before the territory was divided in three parts by Johann der Mittlere. A. Luck, 'Johann Moritz Fürst zu Nassau-Siegen als Landesherr in seinem eigenen Territoriumf', in: Stadtissches Museum Haus Koekoek Kleve, Soweit der Erdkreis Reicht: Johann Moritz von Nassau-Siegen, 1604-1679 (Kleve, 1979), 71-80. 
German nobleman's court, with all its trappings such as artistry, architecture and a passion for gardens and urban design.

\section{The Count, his Court and Slavery}

Within the context of Dutch colonial history in the seventeenth century, the court of Johan Maurits in Brazil is in many ways a singular feature. It is true that other colonial administrators studied botany or extended their patronage to scientists. Architecture was used as a way to underline the prestige of the offices and the individuals holding colonial offices in different occasions. ${ }^{35}$ But in very few instances were scientific, artistic, architectural and social elements combined into as coherent a vision of courtly life overseas as in the case of Johan Maurits in Brazil. Creating a nobleman's court had important ramifications for his position in relation to other company officials in Brazil and the company directors back in the Netherlands. A court did not come cheaply, and complaints of using company materials and indeed company slaves to construct palaces abounds in the WIC sources. ${ }^{36}$ Strikingly, the well-known palaces of Vrijburgh and Boa Vista, built in Mauritsstad, were considered to be private property, not the residence of the governor of Brazil in his official capacity. Apparently, the Jewish community in Recife-Mauritsstad had offered to purchase Vrijburgh for $f 600,000$, but the anger of the Christian residents of the city prevented the sale. ${ }^{37}$ As late as the 1660 s, Johan Maurits claimed damages for the loss of his two palaces to the tune of $f 150,000 .^{38}$ Even before the loss of Recife, he was collecting statements from former inhabitants and army officers who had returned from the city, arguing that the destruction of the palace gar-

35 Hendrik Adriaan van Reede tot Drakensteyn, also a nobleman incidentally, and his Hortus Malabaricus being one good example. J. Heniger, Hendrik Adriaan van Reede tot Drakenstein (1636-1691) and Hortus Malabaricus: A Contribution to the History of Dutch Colonial Botany (Rotterdam: Balkema, 1986). The palace constructed in Colombo at the instigation of Rijckloff van Goens Sr., apparently in an attempt to outdo the Governor-General's palace in Batavia and so underline the claim of Colombo to be a better capital for the East India Company (voc). Odegard, Colonial Careers, 179, 190-192.

36 See for example the lists of bricks used in the period 2 July $1642-30$ June 1643, NL-HaNA, 1.05.01.01, OWIC, inv.no. 58, piece 34, Lijst van de Stenen, Moppen en Klinkers.

37 Moreau, Klare en Waarachtige Beschryving, 32.

38 In accordance with the treaty of The Hague of 1663, Johan Maurits sought recompense for his lost real estate. He claimed that Vrijburgh and Boa Vista had cost him $f_{165}$,ooo, but only submitted $f_{150,000}$ in the claim. Interestingly, he argued he was not obliged to actually prove the expenses or his ownership. Brabants Historisch Informatiecentrum Den Bosch (hereafter, B HIC), 19, Raad van Brabant, inv.no. 429, scan 77-78. 
dens to construct a trench and redoubt during the siege was completely unnecessary. ${ }^{39}$ Perhaps he was already planning a court case against the WIC?

During his tenure in Brazil, one aspect of the costs of a court were consistently devolved to the company: the costs of feeding the entire court. Article eleven of his contract had stipulated that the count 'and his retinue' would receive 'free table', in other words, the company would pay for the cost of feeding Johan Maurits, his household and guests. But this stipulation was stretched well beyond what the directors had likely envisioned when they signed the contract in the summer of 1636 . By March 1643, in addition to Johan Maurits himself, seventy-three European hangers-on and staff of his household were being fed on the company's costs, as well as eighty enslaved Africans, ten 'Turks' and 'one Brazilian from Maranhão' (about whom more later on). ${ }^{40}$ In April 1641, the costs of feeding the entire court were calculated to amount f 9004 and 16 stivers a month. Amongst other things, the court consumed 500 pounds of fresh meat, 350 pounds of salted meat, 175 pounds of butter, thirty pounds of white sugar, four pounds of olives and 126 guilders worth of 'various greens and fruits.'11 The financial costs of backing this courtly enterprise were clearly substantial. But the governability of the colony also suffered from the impact of the court, at least as far as the company in the Netherlands was concerned. By reducing the other members of the High and Secret Council to mere courtiers, their role of counterbalancing the strong position of Johan Maurits was eroded. As the lists of those being fed from the expense agreement with the wIC-directors already show, a large part of the domestic staff of the palace in Mauritsstad was in fact enslaved. This naturally leads us to study slavery at the court of the count.

\section{5}

\section{Slavery at the Court}

Slavery is a key aspect of the tenure of Johan Maurits in Brazil. The topic has garnered some scholarly attention, but little has been written on the personal involvement and stake of Johan Maurits in the slave trade and enslavement. ${ }^{42}$

39 The Hague Notarial Archives, inv.no. 20, folio 549, Attestation, Notary Garbrantsz van Warmenhuijsen, 5-9-1647.

40 NL-HaNA, 1.05.01.01, OWIC, inv.no. 58, piece 206, 1 April 1643.

41 NL-HaNA, 1.05.01.01, OWIC, inv.no. 56, scan 1469-1470.

42 Alencastro, 'Johan Moritz und der Sklavenhandel', 123-144, provides an overview of the importance of slavery to Dutch Brazil. It makes the excellent point that for this period, Angola was more closely integrated into the Brazilian economy than for example Maranhão. 
This is noteworthy since as governor of a colony whose chief export was sugar, Johan Maurits was closely involved with both the organization of the middle passage as well as formulating laws and regulations concerning the treatment of enslaved Africans in Brazil itself. The High and Secret Council over which Johan Maurits presided was not reticent to voice the importance of enslaved labor for Brazil:

It is impossible to achieve anything in Brazil without slaves. Without them, the mills cannot crush the cane, nor can the fields be tilled. The presence of slaves is essential to Brazil, and in no way can we operate without them: if any man feels offended by this, his is a useless scruple. ${ }^{43}$

The main points of embarkation for enslaved people destined for the Dutch colony in Brazil were captured during Johan Maurits's tenure: Elmina in present-day Ghana in 1637 and - much more important for Brazil - Luanda in Angola in 1641. During the final years of his tenure, Johan Maurits was involved in a vehement dispute with the company directors on the position of Angola in relation to Brazil. While Johan Maurits argued that it would be best to rule the entire South Atlantic system as an integrated whole, the company directors categorically refused to entertain this notion. Angola was to be administered separately as the 'Southern district of Africa. ${ }^{44}$ Interestingly, and perhaps showing that there was at least some unease about the topic amongst educated circles in the Netherlands, the figures concerning the mortality rate onboard WIC ships were edited in the Rerum per Octennium. Instead of 1,500 casualties of 6,468 people transported, the text as published by Barlaeus reads 1,500 casualties out of 64,000 people transported. By adding a zero to the total number of enslaved people, the mortality rate was reduced from an imposing $24 \%$ to a mere $2,4 \%$, considerably lower than the mortality of the company's sailors. ${ }^{45}$

Nor did Johan Maurits's involvement with slavery end there. His own court in Mauritsstad was the single largest destination for company-owned slaves in Brazil in 1642. In that year, thirty-five men, seven women and eight children whom the company claimed as being its possession worked at the court of

43 'Sommier Discours over den Staet vande Vier Geconquesteerde Capitanias Parnambuco, Itamarica, Paraiba end Rio Grande in de Noorderdelen van Brasil', Bijdragen en Mededelingen van het Historisch Genootschap 2 (1879): 257-319, 292-293. The English translation appears in Stuart B. Schwartz, Early Brazil: A Documentary Collection to 1700 (Cambridge: Cambridge University Press, 2010), 245.

44 Ratelband, Nederlanders in West-Afrika, 171-172.

45 Benjamin Teensma, 'Review. Caspar van Baerle. The History of Brazil under the Governorship of Count Johan Maurits of Nassau, 1636-1644', Dutch Crossing 41:1 (2017): 94-97. 
Johan Maurits. ${ }^{46}$ Besides these 'company slaves,' Johan Maurits personally must have owned at least thirty more enslaved Africans, as the previously mentioned list of 1643 of the people fed at the court mentions eighty enslaved Africans at the count's court. ${ }^{47}$ Besides these, there were at that time also ten 'Turks' (Turcken) mentioned, probably enslaved as well. The backstory of this group is rather interesting as it shows the different ways in which individuals could end up in enslavement in Brazil. The notarial archives of Rotterdam provide a clue as to how these 'Turks,' in reality Moroccans, ended up in Brazil.

In a declaration of March 22, 1638, Jacob Janzs van der Beets and Harman Matthijsz., respectively first mate and trumpet player attested on behalf of the owners of the ship ' $t$ Vliegend Hardt that the flute Swarten Raven van Hoorn on its way from Norway via Hoorn to Brazil had been captured in full sea in December 1637 by a 'Turckish Polacker', likely a pirate or privateer operating out of Morocco. The captured ship was manned by a prize crew of twelve 'Turks' and two slaves but was captured in turn by the ' $t$ Vliegend Hardt under command of captain Jan Jacob van der Beets. The prize returned to Rotterdam, but the prize-crew was taken in captivity to Brazil, where they would eventually end up at the court of Johan Maurits. ${ }^{48}$

The 'Brazilian from Maranhão', also eating at the expenses of the WIC in Vrijburgh according to the document of 1643, was likely a 'Brasiliano,' an indigenous categorized as 'Tupi' by the colonizers, whose freedom is uncertain during his stay in Mauritsstad. ${ }^{49}$ Immediately after the conquest of Maranhão, the WIC did briefly permit indigenous enslavement, but only of those fighting the WIC. ${ }^{50}$ Nonetheless, by October 1642 , the directors of the WIC recommend, that 'all naturals from Maranhão should be considered free as the other 'Brasilianos' in the colony.51 Gedeon Morris, commander of the Captaincy of Ceará and an advocate of the conquest of Maranhão emphasized, though, that 'those [indigenous] who are free, are free in name only and are in fact slaves.

46 NL-HaNA, 1.05.01.01, OWIC, inv.no. 57, scan 262.

47 NL-HaNA, 1.05.01.01, OWIC, inv.no. 58, scan 832.

48 Rotterdam Municipal Archives, Notarial Archive, akte no. 91a, blz. 133.

49 Mark Meuwese, Brothers in Arms, Partners in Trade: Dutch-Indigenous Alliances in the Atlantic World, 1595-1674 (Leiden, Boston: Brill, 2012), 125. For a further discussion on the terms 'Tupi,' 'Tapuia' and their usage in Dutch Brazil, see: I. Schwamborn, "Brasiliano', 'Tupinambá,' 'Tupi' - 'Tapuya,' 'Tarairiu’: A Questão dos Títulos dos Retratos de Albert Eckhout e de Zacharias Wagener (1641-1643),' in: Tostes, Benchetrit and Magalhães (eds.), A Presença Holandesa no Brasil, 89-144.

5o Gonsalves de Mello, Tempo dos Flamengos, 216-217.

$5^{1}$ Letter from the Heeren XIX to the Supreme Council of October 10, 1642. Cited in Gonsalves de Mello, Tempo dos Flamengos, 217. 
For anyone forced to work for a month for three 'varas' of cloth is virtually enslaved; and that is the standard wage here. 52

\subsection{Purchasing the Enslaved}

But of course the majority of the enslaved at the court, and indeed in the colony, originated from sub-Saharan Africa. A closer examination of the various lists of buyers of newly arrived enslaved people from Africa will highlight the scale of slave purchases on behalf of the court of Johan Maurits. The bills of lading of the ships Poortier, Groote Gerrit and Brack, which arrived from Luanda in January 1644 show an example of what must have been the more usual way for enslaved Africans to end up at the court of Johan Maurits. The three ships had transported a total of 1,096 enslaved people from Luanda to Recife, of whom 196 had died on the passage. The survivors, together with 58 individuals earlier transported by the Uittrecht, were auctioned at Recife for a total sum of $f$ 122,097. ${ }^{53}$ Listed separately from the other purchasers are four individuals in the company's service who together bought 65 individuals. Arnoult L'Hommel in Recife bought one person, the reverend Van der Poel bought two, as did Jan Roolifs. The remaining sixty individuals were sold 'to his Excellency, on the account of the court. ${ }^{54}$ What makes the sale especially striking is the large numbers and the late date. Johan Maurits would leave Brazil in the spring of that year. Given the fact that it is unlikely that the service of the court all at once required so much new labor at the same time, especially given Johan Maurits's pending departure (his dismissal already having been communicated to him in April 1642), it is highly likely that the sixty individuals bought in January 1644 were in fact destined for resale.

Another indication of Johan Maurits as the private owner of enslaved Africans is visually imprinted in a watercolor from the count's quartermaster, Zacharias Wagener (1614-1668). Some of the ethnographic elements reproduced in his Thierbuch are assumed to be a copy of Albert Eckhout's series

$5^{2}$ Letter from Morris to the Chamber of Zeeland, dated from São Luís, April 07, 1642. Cited in Gonsalves de Mello, Tempo dos Flamengos, 217n26. Translated to English by John Hemming: John Hemming, Red Gold: The Conquest of the Brazilian Indians (Cambridge, Mass.: Harvard University Press, 1878), 287.

53 NL-HaNA, 1.05.01.01 OWIC, inv.no. 59, piece 69. The number of people sold at auction, 930, is actually lower than the number of transported individuals, since Liandro de Miranda in Angola and 'various others' transported twenty-six people for their own account, having paid the company the required sums to be allowed to do so.' Twenty breast-feeding babies were not included in the sale, although the document is unclear on their eventual fate. http://proxy.handle.net/10648/63349353-2bob-93a5-b9ff-d9b740854agc.

Ibid. 
TABLE 1 Johan Maurits as purchaser of enslaved Africans in Recife

\begin{tabular}{|c|c|c|c|c|c|}
\hline Ship(s) & From & Date of sale & Number & Price (guilders) & Remarks \\
\hline $\begin{array}{l}\text { Cameel, } \\
\text { Hoop and } \\
\text { St.Jan }\end{array}$ & Guinea & $\begin{array}{l}23 \text { January } \\
1637\end{array}$ & $\begin{array}{l}44 \text { (plus } \\
2 \text { more } \\
\text { gifted) }\end{array}$ & Unspecified & $\begin{array}{l}\text { 'Sijn Ex.cie heeft } \\
\text { behouden vier } \\
\text { en veertich } \\
\text { negros' }\end{array}$ \\
\hline $\begin{array}{l}\text { 'T Wapen } \\
\text { van Delft }\end{array}$ & Guinea & $\begin{array}{l}11 \text { September } \\
1641\end{array}$ & 10 & & $\begin{array}{l}\text { 'aen t Hoff van } \\
\text { sijn Ex.cie' }\end{array}$ \\
\hline Nassau & Guinea & $\begin{array}{l}25 \text { February } \\
1642\end{array}$ & 2 & f9oo & 'aen sijn Ex.cie' \\
\hline $\begin{array}{l}\text { Den } \\
\text { Regenboge }\end{array}$ & Luanda & $\begin{array}{l}\text { 4/5 May } \\
1643\end{array}$ & 2 & $f_{700}$ & $\begin{array}{l}\text { 'aen zijn Ex.cie } \\
\text { Jan Maurits } \\
\text { grave van } \\
\text { Nassau' }\end{array}$ \\
\hline De Moriaen & Luanda & $\begin{array}{l}22 \text { October } \\
1643\end{array}$ & 2 & $\begin{array}{l}\text { [specified } \\
\text { elsewhere, } \\
\text { slaves } \\
\text { manumitted] }\end{array}$ & $\begin{array}{l}\text { 'Aen zijn Ex.cie, } \\
\text { Joan Mauritz, } \\
\text { Graeve van } \\
\text { Nassou } \\
\text { dewelcke } \\
\text { voorgeven doet } \\
\text { vrij sijn' }\end{array}$ \\
\hline $\begin{array}{l}\text { Portier, } \\
\text { Groote Gerrit } \\
\text { and Brack }\end{array}$ & Luanda & $\begin{array}{l}\text { 18/19/20 } \\
\text { January } 1644\end{array}$ & 60 & f $11,981: 8:-$ & $\begin{array}{l}\text { 'Aen zijn Ex.cie } \\
\text { op re. van de } \\
\text { hofhoudingh' }\end{array}$ \\
\hline
\end{tabular}

Source: NL-HaNA, 1.05.01.01, owIC, inv.nrs. 52, scan 197m inv.no. 56, scan 1564, inv.no. 57, scan 1020, inv.no. 58, scan 18, scan 726 , inv.no. 59 , scan 368 . $^{\text {a }}$

Excluded from this list are the ten individuals sold on 20 October 1643 for $f 2220$ to 'Joan Morits' who had been transported to Recife from Angola on the Walcheren. The lack of honorific titles means it is likely that this is another individual named Jo[h]an Morits, although it could be Johan Maurits. NL-HaNA, 1.05.01.01, owIC, inv.no. 59, scan 355.

of eight paintings depicting the inhabitants of Dutch Brazil today at the National Museum of Denmark. ${ }^{55}$ Unlike Eckhout or Frans Post, artists who had

55 Eckhout's paintings are dated 1641 and 1643 and Wagener's watercolours are positioned somewhere circa 1641. We argue, though, that a more thorough investigation regarding these works, dates is still to be performed. Most scholars defend Wagener's book was 


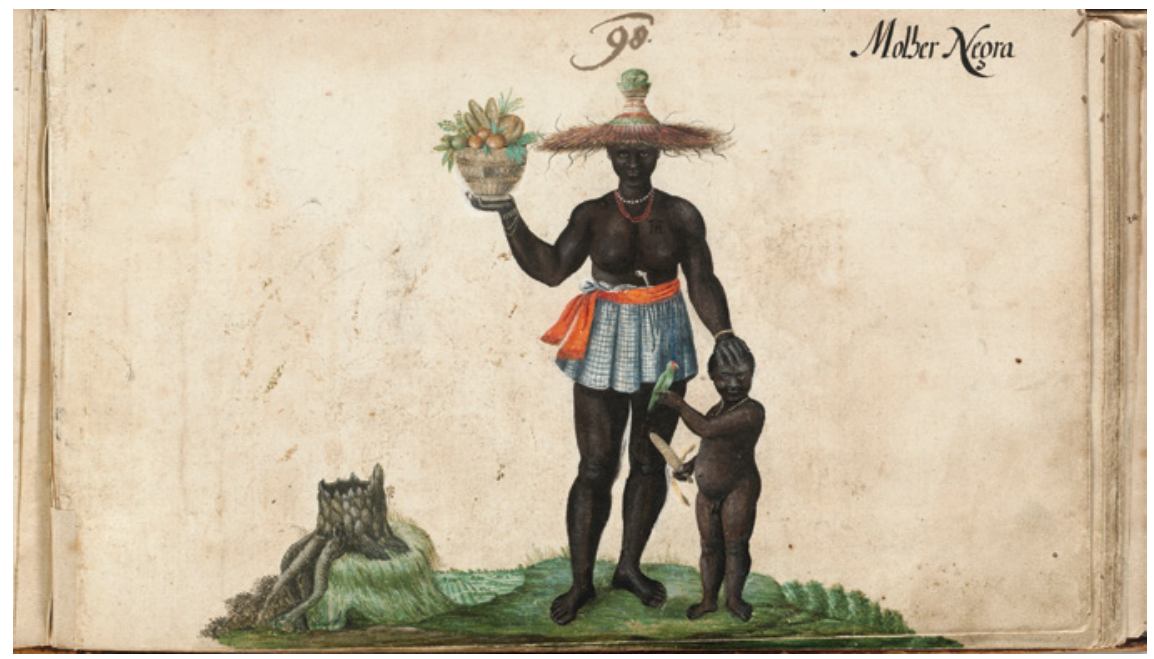

FIGURE 1 Zacharias Wagener, Molher negra

SOURCE: WAGENER'S THIER BUCH, KUPFERSTICH-KABINETT, STAATLICHE KUNSTSAMMLUNG, DRESDEN

been commissioned by Johan Maurits and were part of his entourage, Wagener's intention was to 'depict all the strange things he got as presents from the 'savages.'56 Molher negra [figure 1], watercolor number ninety-eight in his book, is represented by an African woman adorned with pearls and other jewelry. She wears a straw hat and a checked skirt and is carrying a basket of vegetables and fruits and an ivory pipe, while touching the head of a child, presumably her own. The child carries a corncob in one hand and a perroquet in another. This work's resemblance with Eckhout's African woman is largely acknowledged and both representations are usually analyzed regarding their natural elements, their characters' clothes and origins. ${ }^{57}$ Molher negra,

nonetheless based on Eckhout's series. Rebecca Parker Brienen, Visions of Savage Paradise: Albert Eckhout, Court Painter in Colonial Dutch Brazil (Amsterdam: Amsterdam University Press, 2006), 134. Whitehead and Boeseman, A Portrait of Dutch $17^{\text {th }}$ Century Brazil, 86; Quentin Buvelot, Albert Eckhout: Een Hollandse Kunstenaar in Brazilië (Zutphen: Walburg Pers, 2004) 25-26.

56 In the preface of the Thierbuch. Zacharias Wagener, Dante Martins Teixeira (ed.), O Thier Buch e a Autobiografia de Zacharias Wagener, Coleção Brasil Holandês, vol. 2 (Rio de Janeiro: Editora Index, 1997), 26.

57 Brienen, Visions of Savage Paradise, 149, 152. Peter Mason, Infelicities: Representations of the Exotic (Baltimore and London: The Johns Hopkins University Press, 1998), 61-62. Benjamin Schmidt, Inventing Exoticism: Geography, Globalism, and Europe's Early Modern World (Philadelphia: University of Pennsylvania Press, 2015), 187. 
however, presents a unique element, absent in Eckhout's painting: a branding sign. Her chest is marked with a symbol created by the letters 'I' and 'M' overlapping each other under the figure of a crown. The image has been previously associated with Johan Maurits's monogram present in the cover of Barlaeus Rerum per octennium [figure 2], but most researchers who investigated the work did not closely examine the mark. ${ }^{58}$ Other images of the count's emblem reinforce the identification of the branding mark as belonging to Johan Maurits. As part of his gifts to the Elector of Brandenburg in 1652, an ivory chair today in the Sanssouci Palace, is carved with the exact same motif as the one Wagener's woman carries on her chest: Johan Maurits's initials for his name in Latin 'Iohannes Mauritio' adorned by a crown [figure 3].

Not every enslaved person carried the mark of his or her owner, for the right to brand one's slaves had been restricted by Johan Maurits as part of an effort to make some forms of punishment, as well as branding, contingent upon the approval of the Dutch colonial authorities. The practice of branding an enslaved person with a hot iron piece containing different symbols and letters was used to identify not the people in captivity, but to whom they belonged to. Besides attesting their property status, it also showcased the power of their owner. If a branded runaway was captured, their masters could be easily recognized. Their capturer would be rewarded and the master could proceed with exacting the desired punishment on the fugitive. ${ }^{59}$ Making the right to brand the enslaved subject to approval of public authorities of course entrenched the power of the Dutch administration vis-à-vis slave owners. ${ }^{60}$ Johan Maurits, as governor-general, did of course gain permission to brand his slaves. This served as a visual reminder of his power, not only over those humans enslaved at his court, but also over the Luso-Brazilian colonial elite.

The West India Company was interested in Brazil because of the sugar produced there, and slavery and enslavement were crucial to this industry. The directors were well aware of this before contemplating the conquest of Pernambuco or even Bahia in 1624, attested by the fact that even the first attack on Brazil included expeditions against Portuguese positions in Africa. Johan Maurits, as governor of the colony was naturally closely concerned with

58 Brienen, Visions of Savage Paradise, 135. Whitehead and Boeseman, A Portrait of Dutch $17^{\text {th }}$ Century Brazil, 75. Mariana Françozo, "Inhabitants of Rustic Parts of the World': John Locke's Collection of Drawings and the Dutch Empire in Ethnographic Types,' History and Anthropology 28: 3 (December 2016): 363, and Schmidt, Inventing Exoticism, 190-191.

59 In the description of Molher negra, Wagener highlights the practice of branding and its functions inside the colony. Wagener, O Thier Buch, 175.

60 Gonsalves de Mello, Tempo dos Flamengos, 143. 


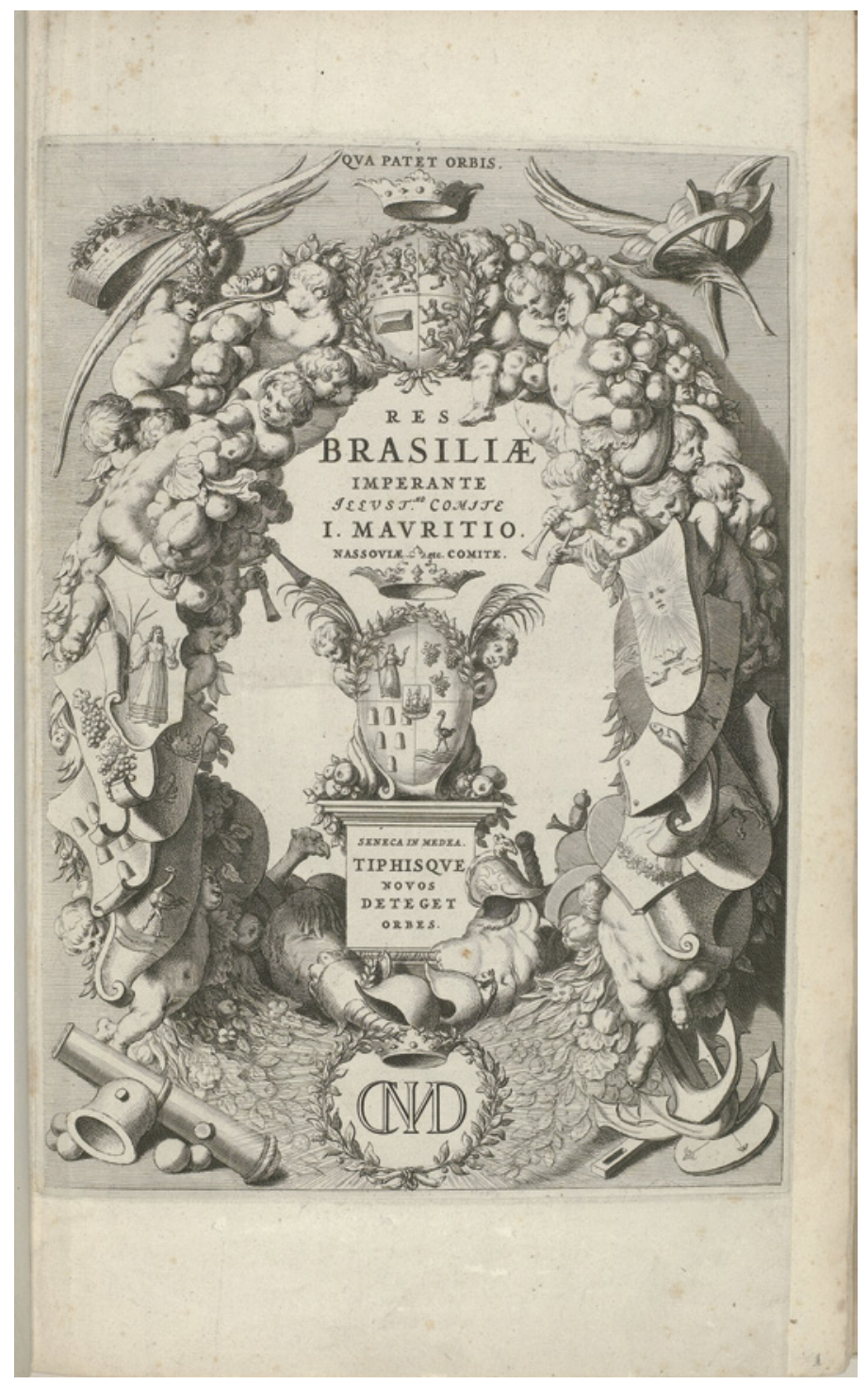

FIGURE 2 Title page of Rerum per Octennium with Johan Maurits's monogram SOURCE: RIJKSMUSEUM BI-1892-3415-1

strengthening the WIC's position in the transatlantic slave trade. But he also had a much more personal stake in the trade: being involved in an illegal - in the eyes of the company at least - slave smuggling venture, importing enslaved Africans from Cape Verde to Brazil. This, at least, is argued by Frei Manuel 


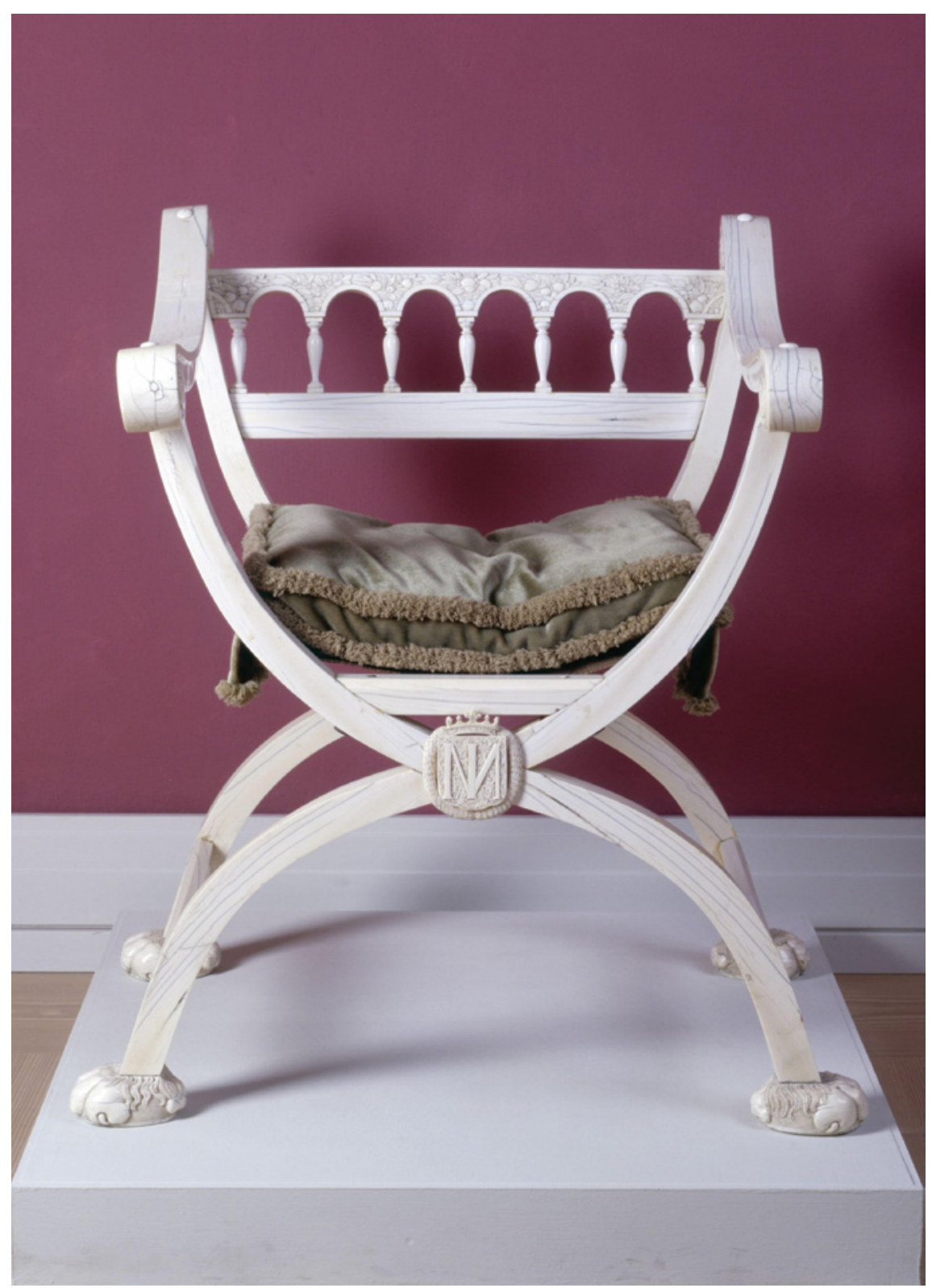

FIGURE 3 Ivory chair with Johan Maurits's monogram

SOURCE: STIFTUNG PREUSSISCHER PALASTEN UND GARTEN: SPSG, HM 2701 / IV 424, PHOTOGRAPHER: WOLFGANG PFAUDER 
Calado in his account of Johan Maurits and his court in Recife. The description of this particular episode not only highlights a new aspect of Johan Maurits's tenure that needs to be examined, it also allows for a further examination of the account of Calado as a source to study Dutch Brazil, comparing his account with Dutch archival material.

\section{The Account of Frei Manuel Calado: Unreliable Gossip or Trustworthy Narrative?}

In 1645, 'obliged by his love to his homeland and in order to encourage those living in Pernambuco carrying the weight of the war to free their land from the Dutch invaders, ${ }^{61}$ Frei Manuel Calado started writing one of the most important testimonies of the period, O Valeroso Lucideno e Triunfo da Liberdade. Its title is considered to be a homage to one of the leaders of the uprising, João Fernandes Vieira. ${ }^{62}$ The narrative begins with the Dutch invasion of Pernambuco in 1630, and ends with the Calado's departure to Lisbon, in 1646. Calado, who calls himself Frei Manuel do Salvador throughout the book and signs official documents as $\mathrm{M}^{\mathrm{el}}$ Callado do Salvador, is also commonly recognized as Frei Manuel dos Óculos by his contemporaries. ${ }^{63}$ In the first chapter of the second book of the Lucideno, the friar states that Vila Viçosa is his hometown and that he was raised at the House of Bragança. He intended to go to Brazil to acquire alms to maintain his father and to get his sister married, which was rather successful, for he ended up owning at least twenty-five slaves. ${ }^{64}$

As an eyewitness of the Dutch period in Brazil, Calado's stay begins in Bahia, where he is assumed to have been imprisoned by Dutch officers during the city's occupation in $1624 .{ }^{65}$ Descriptions of dated episodes indicate the book was written between 1645 and 1646 and, as most historians agree, the volume's intent was to promote the reasons for the uprising in Portugal, claiming the Crown's legitimacy and support against the invaders. Nonetheless, after its first

61 Calado, 'Prólogo ao Leitor'. In: O Valeroso Lucideno, n. p.

62 Not a common term in the Portuguese language, its meaning could be associated with the Latin word 'lucidus', which, in adding the suffix '-eno', could indicate the Lucideno as someone 'naturally enlightened'. Affonso Romano de Sant'Anna, one of the last authors to write about the work of the friar in 2000, is one of the few to highlight the difficulty in deciphering the word 'Lucideno'. Affonso Romano de Sant'Anna, 'O Valeroso Lucideno: Um Caso de Arqueologia Literária,' Revista Convergência Lusíada, 17 (2000): 17-30, 22-23.

63 Gonsalves de Mello, Frei Manuel Calado do Salvador, 28-29, 45, 47.

64 Calado, $O$ Valeroso Lucideno, 6o, 180.

65 Gonsalves de Mello, Frei Manuel Calado do Salvador, 28. 
publication in 1648, the Lucideno was put in the Index of Prohibited Books and its second edition was only published twenty years later, long after the restoration. The suppression of the first edition was likely due to defamatory accusations of ecclesiastic figures made by Calado throughout the book, since its publication had been previously approved by the Reviewer of the Holy Office. ${ }^{66}$ When compared with other works of the seventeenth century, $O$ Valeroso Lucideno stands out for its detailed accounts of the daily life in the colony, the events leading to the restoration and the previous 'Nassovian' government. Manuel Calado was one of the few Portuguese writers on the subject who actually lived in Dutch Brazil and his work served as primary source for other narratives, such as Diogo Lopes de Santiago História da Guerra de Pernambuco, and Frei Rafael de Jesus Castrioto Lusitano ${ }^{67}$ Both works cover the period from the Dutch invasion of Pernambuco until its loss in 1654. Nova Lusitânia and Memorias Diarias de la Guerra del Brasil are also important sources praising the recapture of the territory by the Portuguese. Both narrate the resistance of the moradores during the war, but lack the everyday details only a courtly eyewitness could provide. ${ }^{68}$

After a petition from the Portuguese and Luso-Brazilians of Dutch Brazil, Manuel Calado was summoned by Johan Maurits to move to Pernambuco in order to provide these residents with the profession of the Catholic faith. The count, 'whom was told about the father's virtues and knowledge by the inhabitants of the colony', invited the friar on the occasion of their acquaintance, to reside in Vrijburgh. Politely rejecting the request, Calado later agreed in settling - not in Vrijburgh, but inside the count's fortification in Mauritsstad after Johan Maurits secretly gave him 'the permission to conduct the Holy Mass behind closed doors inside his residence. ${ }^{69}$ Similar interesting episodes are often found in Calado's work, which is indisputably a rich source of information

66 Cabral de Mello, Rubro Veio, 75; Gonsalves de Mello, Frei Manuel Calado, 9-10, 23.

67 Gonsalves the Mello argues that both works use an extensive amount of information from Calado's oeuvre, while Cabral de Mello affirms they were commissioned by João Fernandes Vieira, the Lucideno himself. Gonsalves de Mello, Frei Manuel Calado do Salvador, 28-25. Cabral de Mello, Rubro Veio, 75. Diogo Lopes de Santiago is believed to be a resident of Dutch Brazil at least until 1645, for he says, 'to have escaped an attack from the Tapuia with Jacob Rabi in Paraíba, by hiding himself in the house of Jerônimo Cadena,' around the same time. Diogo Lopes de Santiago, História da Guerra de Pernambuco (Recife: Fundarpe, 1943), 399-40o. Frei Rafael de Jesus, on the other hand, 'has never set foot in Brazil.' Cabral de Mello, Rubro Veio, 65 .

68 Francisco de Brito Freyre's Nova Lusitânia is the only of the five above mentioned volumes to have been translated into the Dutch language in 2018 by Benjamin Teensma in a shortened version entitled: Bahia, Recief en Ander Ongerief: Het Einde van het Nederlandse Tijdperk in Brazilië (Leiden: Primavera Pers, 2018).

Calado, O Valeroso Lucideno, 101-104, 110-111. 
regarding the recently installed court in the northeast of Brazil. Nonetheless, different factors have contributed over the years to put the Lucideno in the margin of historical research. Historians such as Evaldo Cabral de Mello and Affonso de Romano Sant'Anna both recognize the absence of the source in Brazilian historiography, ${ }^{70}$ which is also rarely used as reference by authors of other nationalities. ${ }^{71}$ Therefore, it is safe to say that in the historiography of Dutch Brazil, Calado's book is yet to be the focus of a thorough investigation and Gonsalves de Mello's title of 1954 is still the most up-to-date research on the friar and his œuvre. ${ }^{72}$

$O$ Valeroso Lucideno is free in its composition, including poetry, acclamations, sermons and prose and this multiplicity of styles has been the target of criticism by those who considered it 'badly written' or 'full of useless poetry undermining the historical content' of the facts. ${ }^{73}$ The lack of a translated version, either in English or Dutch, also limits the outreach of Calado's narrative. Nonetheless, when comparing Calado's narrative with the archival documentation of the period the Lucideno proves itself to be an important source for social, cultural and courtly information on Dutch Brazil. ${ }^{74}$ For our purposes, the Lucideno is crucial as it provides an insight into the court of Johan Maurits.

\subsection{Testing Calado: The Case of the Diemen}

One such possibility to test the account of Calado comes from the peculiar arrangement he noted between Johan Maurits and Gaspar Dias Ferreira in trading enslaved Africans to the Brazilian colony in violation of the company's monopoly. The problem in accessing Africa from Brazil was that the WIC had maintained a policy of strict exclusion from the African coast for private

70 Cabral de Mello, Rubro Veio, 75-79; Romano de Sant'Anna affirms the Valeroso Lucideno is 'frozen in Brazil's colonial past' and that but for a few exceptions, it is neglected by literary investigation: Romano de Sant'Anna, 'O Valeroso Lucideno': 17-20.

71 Hermann Wätjen, Das Holländische Kolonialreich in Brasilien: Ein Kapittel aus der Kolonialgeschichte des 17. Jahrhunderts (The Hague and Gotha: Martinus Nijhoff and F.A. Perthes A.-G., 1921), 10-11 criticizes the book for Calado's exaggerated attack on the Dutch invaders. Charles Boxer, The Dutch in Brazil cites the Lucideno in different passages.

72 Some of the contemporary researchers analysing Dutch Brazil who reference Calado include Mariana Françozo, Hebe Mattos, Michiel van Groesen, Liza Oliver, Jeroen Dewulf, and Stuart Schwartz.

73 Wätjen affirms that 'a lot of patience is required from the reader, for Calado's narrative is badly written, containing a strenuous introduction and is full of biblical and classical citations.' Wätjen, Das Holländische Kolonialreich in Brasilien, 37-39; and Pedro Souto Maior denounces Calado as 'ungrateful, hypocritical and disloyal'. Pedro Souto Maior, Fastos Pernambucanos (Rio de Janeiro: Imprensa Nacional, 1913), 73.

74 Gonsalves de Mello is the only researcher to have published his investigations on the veracity of Calado's accounts, in both Tempo dos Flamengos, 36 and Frei Manuel Calado do Salvador, 91-98. 
merchants and inhabitants of its Brazilian colony. The topic of free trade had been hotly debated in relation to Brazil in the second half of the 1630 . The result of this debate had been to open up Brazil to private trade by Dutch holders of wIC stocks, at first in company vessels and later on in their own vessels. ${ }^{75}$ The inhabitants of the colony, too, had been granted a freedom of trade with Europe and along the Brazilian coast, in order to make them amenable to Dutch rule. ${ }^{76}$ But Africa had been very consciously excluded from this opening up of the WIC's monopoly privileges. The trade in gold, ivory, Guinea pepper, and enslaved Africans was simply too profitable to allow competition in the African markets. In the case of Brazil, the proponents of liberalizing trade had won out because they could make a good case that the company by itself could not supply the Brazilian colonies. But these arguments did not apply to Africa. Smuggling enslaved Africans into Pernambuco was thus an important breach of the company's rules.

Calado's disgust for Johan Maurits's right-hand man Gaspar Dias, is noted throughout the book. He blames Dias for Johan Maurits's involvement in the smuggling, for example. Calado, who was a Catholic clergyman, had obvious reasons to dislike both the protestant Dutchmen as well as the Jewish, who "had become rich in a few days after their arrival in Recife, with their scams and frauds. ${ }^{77} \mathrm{He}$ described Dias as being descendent in part from the Hebrew nation, ${ }^{78}$ but it is not clear whether Dias was in fact Jewish. ${ }^{79}$

According to Calado, Gaspar Dias' intent was to create a company to purchase enslaved Africans and wine, two commodities for which there was a substantial market in the colony, guaranteeing good profits. Gaspar Dias' strategy was to send a ship to Cape Verde or Madeira loaded with some money, sugar, Brazilwood and tobacco, to be exchanged for enslaved Africans and wine. Upon its return, he would make sure the vessel disembarked at any port of

75 Henk den Heijer, 'Het Recht van de Sterkste in de Polder: Politieke en Economische Strijd tussen Amsterdam en Zeeland over de Kwestie Brazilië, 1630-1654,' in: Dennis Bos, Maurits Ebben and Henk te Velde (eds.), Harmonie in Holland: Het Poldermodel van 1500 tot Nu (Amsterdam: Bert Bakker, 2007), 72-92.

76 As mentioned in the complaints of the Câmara of Pernambuco to the XIX of May 1637: 'Stukken Betreffende den Vrijen Handel op Brazilië, 1637. Uit het Archief Van Hilten,' Kroniek van het Historisch Genootschap Gevestigd te Utrecht (1869): 191-205, 203-205.

77 Calado, O Valeroso Lucideno, 112-113, 234.

78 Ibid., 114-115.

79 Ineke Phaf-Rheinberger, 'Caspar Barlaeus, Dutch Expansion and the Sephardic Community in the Atlantic World: A Note on the Intellectual History of Amsterdam in the Seventeenth Century', in: Sina Rauschenbach and Jonathan Schorsch (eds.), The Sephardic Atlantic: Colonial Histories and Postcolonial Perspectives (Cham: Springer Nature 2018),

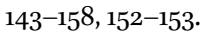


Pernambuco -except Recife. From this point on Gaspar Dias would take all the 'cargo' inland and cautiously sell it, at the discretion of the count. To get the desired produce from the Portuguese ports, he would look for a Portuguese captain and sailors, so as to be able to pretend the vessel had departed from Bahia and not Pernambuco. Johan Maurits agreed, giving Gaspar Dias instructions to purchase a ship which was to be released for sale by the wic. Calado argues the assignment of the crew was a simple task since 'many Portuguese sailors and captains were available and in need after their boats were confiscated at the end of the truce.'80 The High and Secret Council would be informed the vessel 'was heading to Setúbal, to be loaded with salt that should be transported to Holland. ${ }^{81}$ Antônio Machado, the captain assigned to the mission, disclosed to some friends that:

he was embarking on this journey unwillingly, only to be on good terms with Gaspar Dias and the count. He was determined to take the bark to Lisbon and deliver it to the King, and in case the vessel stopped at any other port belonging to the Portuguese Crown, that he would reveal the whole scam to its governors. ${ }^{82}$

After finding out the intention of the Portuguese captain, Gaspar Dias decided to include his own nephew and a brother-in-law in the venture, the first as a merchant and the latter as a shipmaster. To avoid treason, he also saw fit to ask Johan Maurits 'for ten Dutch soldiers and two gunners' as part of the crew, that in the end also included a second Dutch pilot.

Antonio Machado did reveal the scam when arriving in Cape Verde, where the vessel was confiscated. However, after Gaspar Dias's relatives pleaded with the governor and convinced him that they were returning to Bahia, the ship was liberated upon bail of six thousand cruzados. Upon arrival in Pernambuco, Calado states the ship was docked near Porto Calvo, after sailing past Recife camouflaged as a Portuguese vessel. All the cargo was secretly stashed ashore and the ship was destroyed and sunk as per orders of Gaspar Dias. Calado furthermore remarks that the secrecy was not kept. But although the Supreme Council found out about the smuggling, the members of the Council decided to keep it secret because of Johan Maurits's involvement. ${ }^{83}$

\footnotetext{
8o $\quad$ Calado, $O$ Valeroso Lucideno, 234.

81 Ibid., 234 .

82 Ibid., 235 .

83 Ibid., $235^{-236 .}$
} 
Calado's narrative is corroborated by a document from the WIC archives. In a lengthy letter to Johan Maurits and the High and Secret Council in Recife in October 1642 in which the XIX complained, amongst other things, about the high costs of building the bridge between Mauritsstad and Recife, they also brought up the issue of slave-smuggling. The XIX wrote that they could not 'at this opportunity neglect to mention [...] that which we heard from a reliable source.'84 The bark Diemen, which had been captured at Luanda (under a different name) in August 1641 and forwarded to Recife with a cargo of copper, was reported to have been sold for a low price to Gaspar Dias Ferreira. The reason for the sale was the reported poor state of maintenance of the vessel. But Gaspar Dias was quickly able to repair the ship and sent it to Cape Verde to trade in gold, silver and enslaved Africans. The purported goal was to travel to Bahia or elsewhere in Brazil. ${ }^{85}$ Interestingly, the directors mention that they received word of a deed of maritime insurance issued in Amsterdam on the vessel and its cargo of sixty thousand guilders. The directors expressed their surprise at the fact that Gaspar Dias Ferreira was permitted to trade in areas and on coasts 'which the company had thus far reserved for itself at the exclusion of others. ${ }^{\text {' }}$ 'The directors 'seriously desired' to know why this permission had been granted. Despite the efforts to keep the plot a secret, the directors had discovered it nevertheless. Calado mentions that the plot was common knowledge in Recife as well and that it was expected that Johan Maurits would be made to cover the losses to the WIC upon his return to the Netherlands. ${ }^{87}$

Calado affirmed that the enslaved Africans were 'separated in lots and distributed to different clients, to whom they were sold for excessive prices. ${ }^{\prime} 8$ The most interesting account, nonetheless, is described by the friar regarding the 'gifts' Gaspar Dias offered in the name of Johan Maurits. the friar described the episode as follows:

[Caspar Dias] in possession of letters written in the name of and signed by the count, sent a number of enslaved Africans to certain wealthy farmers and sugar mill owners, in lots of six, as presents to be paid whenever and however they saw fit.[but] after eight months, Gaspar Dias forced

\footnotetext{
84 NL-HaNA, 1.05.01.01, inv.no. 9, scan 75 .

85 NL-HaNA, 1.05.01.01, inv.no. 9, scan 75 .

86 NL-HaNA, 1.05.01.01, inv.no. 9, scan 75. Gonsalves de Mello made the connection between the Dutch sources and Calado's account first; Gonsalves de Mello, Frei Manuel Calado, 96-98.

87 Calado, $O$ Valeroso Lucideno, 128.

88 Ibid., 236.
} 
those who accepted the gift to pay up to a hundred thousand reis per slave received. ${ }^{89}$

Not all illegally transported Africans were sold, and Gaspar Dias's solution for the remaining ones was no less opportunistic. After taking them to his motherin-law's engenho [sugar-mill] he mingled the remaining enslaved with others he had previously purchased from Gaspar Francisco and originally came from Minas, Ardra and Calabar. Gaspar Dias intended to disguise the illicitly traded Africans among the ones that had been legally purchased through the WIC, which was rather impossible, 'since the Cape Verdeans themselves were saying where they came from. ${ }^{90}$ This was noticed by the reverend Vincent Joachim Soler in a conversation with French and Dutch merchants, when they saw the enslaved Africans being offered at Gaspar Dias's door and discussed his attempt to cover up the scam. It was with this strategy, nonetheless, that Gaspar Dias succeeded in selling all the remaining Africans from his and Johan Maurits's private trade..$^{91}$

\section{Trading the Enslaved: Other Indications of Participation in the} Slave Trade

The case of Gaspar Dias is not the only one in which the directors complained of too friendly a reply to the requests of Luso-Brazilian elites. In the same letter, the directors also pointed out that those who had purchased ingenios [engenhos], partidos [cane fields under lease from a mill] or other merchandise' on credit should not be allowed permission to leave the colony unless satisfactory bonds had been deposited to guarantee the payment of the whole sum. ${ }^{92}$ Although this criticism also applied to Dutch or other European inhabitants of the colony who wished to leave, it reinforces the impression that the XIX considered the Governor and the High and Secret Council as too friendly to the colonists, including the Luso-Brazilian elite. This impression is boosted by other information. Johan Maurits had in fact loaned money to some senhores de engenho [sugar-mill owners] who were heavily indebted to the wIC: João

\footnotetext{
89 Calado, $O$ Valeroso Lucideno, 236.

9o Ibid., 237.

91 Ibid., suppress. Calado stresses Soler was somehow aggravated with Johan Maurits at the time, for the count had turned down the love of his daughter Margarida.

92 NL-HaNA, 1.05.01.01 OwIC, inv.no. 9, scan 62. For the partido, see: Stuart B. Schwartz, Sugar Plantations in the Formation of Brazilian Society (Cambridge: Cambridge University Press, 1985), 297.
} 
Fernandes Vieira, Jorge Homem Pinto and Miguel Fernandes de Sá, amongst others. $^{93}$

The case of slave-smuggling from Recife with the tacit permission or active cooperation of Johan Maurits was further reinforced when Reinier Adriaensz Schagen, captain of the WIC-ship Princesse, declared that he had loaded fiftyfive enslaved Africans on the orders of the directors of Angola, Adriaen van Nieulandt and Pieter Moorthamer, for the personal account of Johan Maurits in Angola in September 1642 and had transported them to Recife, where they were brought on land at Vrijburgh Palace. This group of people was distinct from the other enslaved transported on the vessel, ate on a separate $b a k$, were recorded on a separate cognossement, which was destroyed upon delivery of the people to Vrijburgh.$^{94}$ This ties in well with a request that must have originated from the court of the count, but was presented to the States-General in March 1642 by count Hendrik van Nassau, the younger brother of Johan Maurits. It was argued that Johan Maurits's income was much depleted now that hostilities had ceased with Portugal and prizes could no longer be taken. Additionally, the reduction of the expenses for board which the xIX enforced at this moment also weakened Johan Maurits's financial position. It was therefore requested that he be allowed 'at his own costs and risk' to purchase four to five hundred slaves in Angola and to transport them to Recife. The StatesGeneral approved of the idea in principal, but forwarded the request to the XIX. ${ }^{95}$ The fact that requests of this nature were submitted to the StatesGeneral instead of the XIX directly, highlights the growing tensions between the governor in Brazil and the Company directors in the Netherlands. The final decision on the request is unknown.

There is one final route by which enslaved Africans passed into the ownership of Johan Maurits to be sold on for personal profit: diplomacy. When diplomatic missions from the West African states of Sonho, Kongo and Matamba visited Recife, sometimes on their way to the Netherlands, they exchanged gifts with the WIC command in Brazil. Famous gifts include a silver bowl which

93 BHIC, 19, Raad van Brabant, inv.no. 429, scan 78. This is an interesting source which has not previously been used, but which contains a fascinating account of financial claims and investments regarding Dutch Brazil.

94 Amsterdam Municipal Archives, Archives of Notaries, 5075, inv.no. 1287, notary Hendrick Schaef, 8 August 1643, f. 142v-143, '... hoe en wat persoonen aen een back souden eeten, op dat die aen geen andre bacx souden komen.' The word bak is used to denote a group of people, often sailors, who ate and served as a unit, hence backsgasten. This indicates that perhaps these people were served different food than the others. Our thanks to historian Mark Ponte for providing us with this reference and kindly allowing us to use his transcription.

NL-HaNA, 1.o1.o2, Staten-Generaal, inv.no. 4845, scan 93. 
ended up in the church in Siegen as a baptismal font, and beaver-fur hats which were given to the king of Kongo. ${ }^{96}$ Dom Garcia, the King of Kongo also presented two hundred slaves. Crucially, these did not pass into the ownership of the WIC, but rather into the private ownership of Johan Maurits, who would include the gifts exchanged on his copy of a letter by Dom Garcia, writing: '... And two hundred slaves or moors received, who have been sold to the West India Company in Brazil.97 Two hundred slaves could easily fetch seventy thousand guilders in Recife, or more than three years' worth of Johan Maurits's salary, illustrating the potential profits to be made with the trade in enslaved Africans..$^{98}$ Finally, a good indication that Johan Maurits indeed had acquired substantial sums of money which he could not readily transport to the Netherlands without raising suspicion is found in the loans mentioned earlier. A total of $f 75,666.12$ was lent to elite Portuguese men in Brazil. All but 4504 guilders of this substantial sum were loaned after March 1642, when the first rumors of his dismissal were beginning to circulate in Brazil. Credit, payable in Amsterdam, would be an excellent method of laundering the proceeds of business ventures which had broken the wiC regulations.

\section{Conclusion}

Johan Maurits van Nassau-Siegen as Captain- Admiral and Governor-General of Dutch Brazil presided over a colonial venture which was focused on cultivating sugar using unfree labor. Despite the obvious importance of slavery to the colony and therefore to the tenure of Johan Maurits, the histories of the count and his court and of slavery in Dutch colonial Brazil are presented as separate.

96 Mariana Françozo, 'Global Connections: Johan Maurits of Nassau-Siegen's Collection of Curiosities', in: M. van Groesen (ed.), The Legacy of Dutch Brazil (Cambridge: Cambridge University Press, 2014): 105-123, 113-114; Mariana Françozo, De Olinda a Holanda: O Gabinete de Curiosidades de Nassau (São Paulo: Editora UnICAMP, 2014), 118-127.

97 Hessisches Haubtstaatsarchiv, Abt. 171 No. Z 4305. 'Missive Von Dem König Von Congo in Angola ahn Prins Morits van Nassaw in Brasil. Beneben einer großen gülden Kette undt Silbernem Lampet, welches der Kirchen zu Sigenm zum Dauffbecken ver Ehrtt hab. Undt zwo hundert schlaven oder moren ver Ehrett, Welck ahn die West-Indische Compagnie in Brasil verkaufft.' Jeroen Dewulf, 'Emulating a Portuguese Model: The Slave Policy of the West India Company and the Dutch Reformed Church in Dutch Brazil (1630-1654) and New Netherland (1614-1664) in Comparative Perspective', Journal of Early American History 4:1 (2014):3-36, 4, mentions that Sonho offered two hundred, while Congo offer seven hundred slaves. We have opted to use the figure mentioned in the letter. Françozo, $D e$ Olinda a Holanda, 119, also mentions two hundred.

98 Assuming an average sale price of $f 300$ to 400 per person. Pieter C. Emmer, De Nederlandse Slavenhandel, 1500-1850 (Amsterdam: De Arbeiderspers, 2000), 44. 
Recently, historians have argued that there was 'no proof' for a personal involvement of Johan Maurits in the trade of enslaved Africans. Yet a rigid modern distinction between personal and professional involvement in the slave trade does not make sense for the seventeenth century. There is in fact strong evidence from a wide variety of sources that indicate that Johan Maurits profited personally from the trade in enslaved Africans and dabbled in slavesmuggle ventures as well. Combining information from the archives of the Company, the States General, notarial archives, financial claims later put out by Johan Maurits himself, and the published account of Frei Manuel Calado as well as the use of Johan Maurits's personal monogram as a branding mark, this article shows the extent of his involvement. This should not be surprising. In a colonial society in which slaves were both an important form of capital, credit and social prestige, the personal involvement of a governor-general in the trade and sale of enslaved people is in accordance with the standards of the time. Indeed, involvement in smuggling and other ways to enrich oneself above and beyond regular salaries appears to be the rule in the seventeenthcentury Dutch empire. ${ }^{99}$ Distributing illegally procured enslaved Africans, for example, furthered the social position of the count vis-à-vis the Luso-Brazilian elites. On the other hand, seeking Johan Maurits's protection and support would also be a way for these elites to coopt him in their ventures and so ultimately break the WIC's control. Attempts to separate the count and his court from the realities of the social and economic model of the colony retains the outmoded idea of the 'enlightened prince in the tropics', unencumbered by the problematic aspects of the Dutch presence in Brazil.

\section{Acknowledgements and Funding Information}

We would like to thank the three anonymous reviewers for their feedback and suggestions on an earlier version of this article. This research was partially funded by the European Research Council (ERC) Horizon 2020 Research and Innovation Program Grant (Grant Agreement Np. 715423), ERC Project BRASILIAE: Indigenous Knowledge in the Making of Science, directed by Dr. M. Françozo at Leiden University, a personal grant by the Johan Maurits Compagnie at the Royal Picture Gallery Mauritshuis, and the Gieskis-Strijbis fonds.

99 Odegard, Colonial Careers, 78-82, 194-195, 197-198, presents examples from the Dutch East India Company. 